\title{
Focus
}

\section{De Geest onderscheiden}

\author{
C. van der Kooi
}

Willem Maarten Dekker en Andries Zoutendijk, De Geest onderscheiden. Een bijbels-theologische, theologiehistorische en dogmatische studie over de heilige Geest als persoon (Utrecht: Boekencentrum, 2017), 208 p., $€ 24,99$ (ISBN 9789023950578).

De bovengenoemde studie kan in allerlei opzichten een rijk boek genoemd worden. Het boek is rijk omdat er een schat aan kennis en inzichten aan de lezer wordt getoond, vrucht van jarenlang geduldig lezen, analyseren en overwegen. De studie laat zich dan ook gebruiken als een werk waarin in vrij kort bestek een overzicht - hoewel onvermijdelijk ook weer selectief - wordt gegeven van de manier waarop in kerk en theologie gedacht is over de personaliteit van de Heilige Geest. Is de Heilige Geest persoon, of is de Geest een kracht, of beide? Het is niet zonder reden dat de kerk pas op het einde van de vierde eeuw tot een aantal formuleringen kwam omtrent de Heilige Geest die de status van dogma gekregen hebben. Dat dogma behelsde de beslissing van de kerk ten aanzien van hoe we in de christelijke kerk over Gods Geest spreken in onderscheid van het spreken over God de Vader en God de Zoon. Ik kan het boek aanbevelen aan ieder die meer wil weten over deze thematiek. De kwalificatie 'rijk' is zeker van toepassing op de bijbels-theologische hoofdstukken en op het theologiehistorische deel. Die onderdelen getuigen van grote belezenheid, inzicht, en het vermogen om bepaalde lijnen te trekken en tot conclusies te komen. Dat heeft allemaal zeker het niveau waarop men iemand tot de verdediging van een werk als proefschrift toelaat.

Als voorbeeld van inhoudelijkheid noem ik wat dit boek biedt over wat Paulus in Romeinen 8 zegt over de Geest. In het woord vooraf geven de auteurs zelf aan dat hier met name de noeste arbeid van Andries Zoutendijk aan ten grondslag ligt. Hij laat zien hoe Paulus in Romeinen 8 terugkomt op onderwerpen die in de eerdere hoofdstukken zijn besproken, maar nu, in het achtste hoofdstuk, terugkomen onder een nieuwe belichting: de ervaring in de gemeente van de Heilige Geest. In wat we lezen over het geestbegrip bij Pau- 
lus, en verder ook bij Lucas en Johannes, wordt duidelijk dat de ervaring van het werk van de Geest een pijler is geweest in het ontstaan van de christelijke gemeente. De Heilige Geest krijgt bij deze bijbelschrijvers de rol van actor, initiator, en die eigenheid kunnen we niet zonder meer vereenzelvigen met Jezus Christus als de verhoogde Heer. De Geest staat wel nauw in verband met de verhoogde Heer.

De identiteitsteksten, die nog door bijvoorbeeld H. Berkhof werden gebruikt om de identiteit van de Geest en Christus te verdedigen, worden in dit werk anders uitgelegd. Ik was verheugd dat de auteurs daarbij aan de dissertatie van J.P. Versteeg uit 1971 - dit boek had natuurlijk al lang moeten worden vertaald! - het volle pond geven. Ze onderstrepen de beslissende betekenis van de Geest voor het nieuwe verbond in de eindtijd. Christus en de Geest horen onlosmakelijk bij elkaar, en vormen een eschatologische eenheid, maar geen identiteit (42-43). Dat wijst erop dat de heilsgeschiedenis nog niet aan haar einde is en nog niet voltooid. De Geest is de trekkracht die ons aan Gods in Christus gerealiseerde werk deel wil geven. Ik kom daar beneden nog op terug.

De Geest onderscheiden - toen ik voor het eerst van deze titel hoorde, dacht ik: dit is een boek over de taak om de geesten te onderscheiden. Dat is namelijk eveneens een hot issue in de christelijke kerk en de wereld waarvan zij deel uitmaakt. Dat bleek echter niet het geval te zijn; het is een studie waarin het eigene van de Geest als persoon aan de orde is. Is die Geest eigenlijk wel persoon te noemen? Wanneer ik heel kort de these die in dit boek verdedigd wordt moet samenvatten is het dit: de Heilige Geest is persoon omdat Hij een instantie is die zelf kan horen en spreken, en in dit horen en spreken zichzelf is (179).Zoutendijk en Dekker richten zich in deze these tegen een ontwikkeling in de theologie van de westerse kerk waarin de eigenheid van de Geest als persoon vaag blijft, of sterker nog, miskend wordt. De westerse kerk gaat uit van de eenheid van God en dan komt de drievuldigheid eigenlijk in het gedrang.

De auteurs wijzen in dit verband Augustinus aan als een der hoofdschuldigen, bij hem begon het allemaal. Augustinus denkt zich de drieheid als relaties binnen een menselijk bewustzijn. Maar als je zo begint kom je uit ofwel bij een verwatering van het persoonsbegrip ofwel bij een modalistische tendens. Dan zijn de Zoon en de Geest concretiseringen van de ene God, maar geen eigen instantie, hypostase of instantie meer. We vinden die tendens bij bijvoorbeeld Berkhof, bij Schoonenberg, en ook Calvijn ontkomt er niet aan. Uitvoerig gebruiken de auteurs de studie van Arie Baars Om Gods verhevenheid en zijn nabijheid. De Drie-eenheid bij Calvijn, maar of ze geheel naar Baars geluisterd hebben betwijfel ik. Zelf gaan ze een andere weg. Althans, zo moet ik zeggen, in het laatste, afsluitende hoofdstuk wordt een weg gegaan die mij voorkwam als een breuk met het voorgaande. 


\section{Vragen}

Met betrekking tot het dogmatische deel kom ik wel met enige kritische vragen. Dit laatste hoofdstuk heeft de bedoeling systematisch-theologische conclusies te trekken en dat is op zich begrijpelijk en toe te juichen, maar de manier waarop dit gebeurt geeft mij te denken. Allereerst lees ik hier zinnen over de taak van de dogmatiek die ik zo op de voorgaande bladzijden nog niet was tegengekomen. Op pagina 178 heet het bijvoorbeeld: "Wij beschouwen het trinitarische persoonsbegrip dus niet als iets dat direct uit een eerste naïeve of historisch-kritische lezing van de Schrift af te leiden valt. Maar als iets dat zich aan ons opdringt vanuit de doordenking van de heilseconomie die Golgotha als centrum heeft." In voorgaande zinnen is de eigenheid van de Heilige Geest als persoon al afgeleid uit de kruisdood. Daar, op Golgotha, zo lezen we, worden Vader en Zoon uit elkaar getrokken en het is alleen de Geest die Hen tezamen houdt. De Heilige Geest is hier noodzakelijk in de zin dat Hij in de nood van deze verlatenheid en distantie de kloof overbrugt. Er staat net niet dat de Heilige Geest in dit gebeuren ontstaat, wel dat de drie-enige God aan het kruis het meest zichzelf is.

Mijn eerste vraag is of deze afleiding van de personaliteit van de Geest uit het kruis werkelijk nodig was gezien wat het boek eerder allemaal geleverd heeft aan pneumatologische reflectie, bijvoorbeeld van Irenaeus en met name van Basilius van Caesarea. In de vierde eeuw is de indirecte articulatie van de Geest als persoon in het concilie van Constantinopel de vrucht van doxologie en liturgie, van ervaring van de Geest in de gemeente en het leven van de gelovigen. Het is deze ervaringsbasis die de concilievaders ertoe heeft gebracht om ten langen leste tot hun door de liturgie gestempelde formulering ('die samen met de Vader en de Zoon aanbeden wordt') te komen. De theologische reflectie volgde hier de liturgische praktijk, preciezer de gebedspraktijk.

Een krachtig argument voor de personaliteit van de Geest als eigen instantie vinden we ook bij Lukas in het tweede deel van het boek Handelingen en in Romeinen 8, waar ik al eerder naar refereerde. Het mooie van De Geest onderscheiden is er mede in gelegen dat dit alles in zijn rijkdom voor de lezer wordt uitgespreid als op een kleed. Het laatste hoofdstuk vouwt het kleed evenwel weer tezamen, maakt geen gebruik van die rijkdom en probeert het met een afleiding van de personaliteit van de Geest uit het kruisgebeuren. Ik noem dat stauromonisme, waartoe de eerste hoofdstukken juist niet uitnodigen. Wat voor stem klinkt hier? Is het de stem van Moltmann, van Jüngel, die stelde dat God zich definieert aan het kruis? Is het de stem van Bram van de Beek die het geheel van de christelijke theologie op de ene noemer van het kruis wil brengen? Het lijkt mij toe dat, door de Geest als persoon af te leiden uit het kruis, 
een reductie plaatsvindt, die niet nodig was, in de gereformeerde theologie nooit is gedaan en zich uiteindelijk ook wreekt.

Vermoedelijk heeft het nog met iets anders te maken - mijn tweede vraag namelijk met de taak die aan de dogmatiek wordt toegedicht en met name aan de triniteitsleer. Op pagina 179 lezen we: "De triniteitsleer is echter niet bedoeld om contradicties uit te zeggen, maar om deze op te lossen." Als dat waar is moet ik mijn opvatting van dogmatiek herzien en aan al mijn studenten excuses aanbieden. Het dogma, en ook de triniteitsleer was er niet voor bedoeld om contradicties op te lossen, of een speculatieve doordenking aan te bieden, maar om het geheim van de incarnatie, het Woord dat vlees geworden is, te bewaren. De vroege kerk heeft daarbij wel degelijk uitspraken gedaan die in die tijd ronduit als contradictie werden ervaren, namelijk waarlijk God, waarlijk mens, God in het vlees. Zulke formuleringen zijn geen oplossingen, maar willen het geheim bewaren, en bij het geheim bewaren.

Daardoor kan de theologie vaak niet met één woord spreken, maar moet ze verschillende begrippen op verschillende niveaus samen houden, samen blijven zeggen. Een speculatieve doordenking en afleiding vinden is een bezigheid die tot hoogste taak werd gesteld in het $19^{\mathrm{e}}$-eeuwse idealisme. Mijn vraag is of dit laatste hoofdstuk in zijn speculatieve teneur en taakstelling van de dogmatiek niet te veel in de leer is geweest bij August Isaak Dorner en zijn kornuiten, onder wie Karl Barth en Pannenberg - allemaal denkers die een doordenking wilden geven in plaats van een belichting.

Ik noem nog een derde punt uit het laatste hoofdstuk dat wat mij betreft aanleiding is tot vragen. Resoluut wordt daar de knoop doorgehakt dat wel de Vader, Zoon en Geest persoon kunnen worden genoemd, maar dat persoonzijn niet op de ene God van toepassing is. Werkelijk? Zeker, er wordt een rationeel argument voor gegeven. Van J.G. Fichte wordt overgenomen dat het begrip persoon zich niet verdraagt met oneindigheid. Personaliteit betekent altijd iets erkennen buiten de persoon en dat geldt inderdaad voor de Vader, de Zoon en de Geest die in hun betrokkenheid op elkaar niet volstrekt identiek zijn. Er wordt in dit verband ook afgerekend met de oude dogmatische regel 'opera trinitatis ad extra indivisa sunt'. Neen, zo lezen we, we ervaren in eigenlijke zin alleen de Heilige Geest - niet alle drie de personen - ongedeeld. Ook dit is een radicale oplossing, maar laat ik me beperken in mijn kritiek tot de stelling dat aan de ene God geen personaliteit toekomt.

Op bladzijde 186 wordt erkend dat die keuze wel leidt tot een vraag aan jodendom en islam, namelijk of JHWH en Allah eigenlijk wel persoon kunnen zijn zonder afhankelijk te zijn van de mens. Persoon word je immers aan en door de ander, en als dat niet de andere goddelijke personen zijn dan kunnen Allah en JHWH alleen aan de mens persoon worden. Ik constateer dat de 
radicale keus om het persoonsbegrip exclusief toe te passen op Vader, Zoon en Geest, gevolg is van de genoemde taakstelling: een aporie oplossen. Ik zou hiertegen in willen brengen - met Jüngel - dat we sommige aporieën moeten volhouden, beschermen en de verleiding moeten weerstaan om ze op te lossen. Dat laatste lijkt me ook dichter te liggen bij de weg die de vaders van Constantinopel gingen. En trouwens, wat heeft een dergelijke dogmatische solutie voor gevolgen voor het gebed? Mag een mens nog tot de ene God bidden? We aanbidden niet zijn oneindig leven, we richten ons tot de drie-enige God. Het persoon-zijn van God geldt zowel op het niveau van de eenheid als op niveau van de drieheid, en deze beide niveaus zou ik niet willen reduceren tot een van beide. Dat lijkt mij in te gaan tegen de werkelijkheid van het gebed. Baars heeft laten zien dat Calvijn aan beide tracht recht te doen.

Ik noem nog een vierde punt. In het vierde hoofdstuk lezen we: "Het voleindigen [als taak van de Geest] veronderstelt dat God uit-gesproken is." Dat betekent "dat de (heils)geschiedenis met de opstanding van Christus voltooid is. De rest is afwerking" (184). God uitgesproken? Ik hoop het niet, en de hoofdstukken 1-3 geven er allerminst aanleiding toe dat te denken. Ja, het is Barth die zo sprak en ook Van de Beek heeft zich in die zin uitgelaten. Het doet evenwel geen recht aan het eigene van de Geest die ons wil hebben waar de verhoogde Heer is en waar wij nu nog niet zijn. De heilsgeschiedenis is nog niet af. De Geest is juist nog bezig. Dat laat Lukas zien, daarvan getuigt Paulus in Romeinen 8 en daarvan getuigt het laatste bijbelboek. De heilsgeschiedenis is pas af als de laatste bazuin heeft geklonken.

Samengevat: op grond van de eerste drie hoofdstukken hadden in het laatste hoofdstuk ook heel andere conclusies kunnen worden getrokken ten aanzien van de taak van de dogmatiek, ten aanzien van de personaliteit van de ene God en ten aanzien van de heilsgeschiedenis als doorgaand gebeuren in de Geest.

Ik kom tot een afrondende conclusie. Dit is een rijk, goed geschreven boek, met heel veel materiaal; het heeft de kwaliteit van een dissertatie. De centrale these van deze studie betreft het persoon-zijn van de Geest, in onderscheidenheid van de Vader en de Zoon. Daarin ligt een grote theologische verdienste, juist tegenover de tendensen om die personaliteit te verwateren; hier sluit het boek ook aan bij de nieuwere aandacht voor het eigene van de Heilige Geest. Het is naast een rijk ook een intrigerend boek, juist omdat het laatste hoofdstuk prikkelt tot tegenspraak en de lezer doet terugbladeren naar de eerdere hoofdstukken. 